Article

\title{
Targeting and Photodynamic Killing of Cancer Cell by Nitrogen-Doped Titanium Dioxide Coupled with Folic Acid
}

\author{
Jin Xie, Xiaobo Pan, Mengyan Wang, Longfang Yao, Xinyue Liang, Jiong Ma, Yiyan Fei, \\ Pei-Nan Wang and Lan Mi *
}

Department of Optical Science and Engineering, Shanghai Engineering Research Center of Ultra-Precision Optical Manufacturing, Green Photoelectron Platform, Fudan University, 220 Handan Road, Shanghai 200433, China; jinxie13@fudan.edu.cn (J.X.); xiaobopan11@fudan.edu.cn (X.P.); mengyanwang14@fudan.edu.cn (M.W.); yaolongfang@126.com (L.Y.); liangxy14@fudan.edu.cn (X.L.); jiongma@fudan.edu.cn (J.M.); fyy@fudan.edu.cn (Y.F.); pnwang@fudan.edu.cn (P.-N.W.)

* Correspondence: lanmi@fudan.edu.cn; Tel.: +86-21-6564-2092

Academic Editor: Luigi Pasqua

Received: 27 April 2016; Accepted: 1 June 2016; Published: 14 June 2016

\begin{abstract}
Titanium dioxide $\left(\mathrm{TiO}_{2}\right)$ has attracted wide attention as a potential photosensitizer (PS) in photodynamic therapy (PDT). However, bare $\mathrm{TiO}_{2}$ can only be excited by ultraviolet illumination, and it lacks specific targeting ligands, which largely impede its application. In our study, we produced nitrogen-doped $\mathrm{TiO}_{2}$ and linked it with an effective cancer cell targeting agent, folic acid (FA), to obtain $\mathrm{N}-\mathrm{TiO}_{2}-\mathrm{FA}$ nanoconjugates. Characterization of $\mathrm{N}-\mathrm{TiO}_{2}-\mathrm{FA}$ included Zeta potential, absorption spectra and thermogravimetric analysis. The results showed that $\mathrm{N}-\mathrm{TiO}_{2}-\mathrm{FA}$ was successfully produced and it possessed better dispersibility in aqueous solution than unmodified $\mathrm{TiO}_{2}$. The $\mathrm{N}-\mathrm{TiO}_{2}-\mathrm{FA}$ was incubated with human nasopharyngeal carcinoma (KB) and human pulmonary adenocarcinoma (A549) cells. The KB cells that overexpress folate receptors (FR) on cell membranes were used as FR-positive cancer cells, while A549 cells were used as FR-negative cells. Laser scanning confocal microscopy results showed that $\mathrm{KB}$ cells had a higher uptake efficiency of $\mathrm{N}-\mathrm{TiO}_{2}-\mathrm{FA}$, which was about twice that of $\mathrm{A} 549$ cells. Finally, $\mathrm{N}-\mathrm{TiO}_{2}-\mathrm{FA}$ is of no cytotoxicity, and has a better photokilling effect on $\mathrm{KB}$ cells under visible light irradiation. In conclusion, $\mathrm{N}-\mathrm{TiO}_{2}-\mathrm{FA}$ can be as high-value as a PS in cancer targeting PDT.
\end{abstract}

Keywords: titanium dioxide nanoparticle; photodynamic therapy; cancer cell targeting; folic acid

\section{Introduction}

Photodynamic therapy (PDT) based on the photochemical reactions of photosensitizer (PS) is a noninvasive and mild medical treatment for cancer diseases [1-4]. Titanium dioxide $\left(\mathrm{TiO}_{2}\right)$ nanoparticles (NPs) have been widely used as photocatalysts, photochromics and photovoltaics due to their excellent photoreactivity [5-7]. Recently, $\mathrm{TiO}_{2}$ has attracted more attention as a potential PS in PDT due to its high chemical stability, excellent oxidation capability and low toxicity [8-10]. Under ultraviolet (UV) irradiation, $\mathrm{TiO}_{2}$ can be activated and generate cytotoxic reactive oxygen species (ROS). However, UV light is also harmful to normal cells or tissues and has a limited penetration distance in tissues. To enhance the visible light absorption of $\mathrm{TiO}_{2}$, various attempts have been made by dye-adsorbed $[11,12]$ or doping methods $[13,14]$. Moreover, a major challenge for the application of $\mathrm{TiO}_{2}$ in PDT is its lack of specific targeting ligands. To improve the cancer cellular uptake of $\mathrm{TiO}_{2} \mathrm{NPs}$, specific ligands, such as monoclonal antibodies, peptides and aptamers binding to specific proteins or surface antigens, could be coupled with $\mathrm{TiO}_{2} \mathrm{NPs}$. For example, it has been found that folate receptor (FR) is overexpressed on the surfaces of many human tumor cells, whereas it expresses little on the 
surface of normal cells $[15,16]$. Folic acid (FA) has high affinity to FR, which can serve as a good tumor marker for targeting treatment in PDT. Although the use of FA to target FR over-expressed tumor cells were studied in depth for various nanomaterials such as $\mathrm{ZnO}$ nanoparticles [17] and Au nanorods [18], FA functionalized $\mathrm{TiO}_{2}$ NPs with enhanced visible light absorption has not been explored. Recently, the Lee Wen-Chien team modified $\mathrm{FA}$ on $\mathrm{TiO}_{2} \mathrm{NPs}$, and used the obtained $\mathrm{FA} / \mathrm{TiO}_{2}$ as a $\mathrm{PS}$ under UV light [19]. However, UV light itself can have a photokilling on all cells, so it is not encouraged in PDT application. Herein, we reported a promising PS, nitrogen-doped $\mathrm{TiO}_{2}$ with FA on its surface $\left(\mathrm{N}-\mathrm{TiO}_{2}-\mathrm{FA}\right)$. The prepared $\mathrm{N}-\mathrm{TiO}_{2}-\mathrm{FA}$ NPs were characterized by Zeta potential, absorption spectra and thermogravimetric analysis. In this study, human nasopharyngeal carcinoma (KB) cells and human pulmonary adenocarcinoma (A549) cells were used as FR-positive and FR-negative cell lines, respectively. The targeting efficiency of $\mathrm{N}-\mathrm{TiO}_{2}-\mathrm{FA}$ for different cells was studied by laser scanning confocal microscopy. Finally, the cytotoxicity and photokilling effect of $\mathrm{N}-\mathrm{TiO}_{2}-\mathrm{FA}$ under visible light irradiation were researched.

\section{Results}

\subsection{Preparation and Characterization of $\mathrm{N}-\mathrm{TiO}_{2}-\mathrm{FA}$}

Figure 1 shows the synthesis procedure of $\mathrm{N}-\mathrm{TiO}_{2}-\mathrm{FAs}$. The nitrogen-doping $\mathrm{TiO}_{2}\left(\mathrm{~N}-\mathrm{TiO}_{2}\right)$ NPs were first obtained by calcination of pure $\mathrm{TiO}_{2} \mathrm{NPs}$ in ammonia atmosphere for higher visible light absorbance in the range of 400-550 nm [20]. Using amino silanization method [21], the $\mathrm{N}-\mathrm{TiO}_{2}$ NPs were modified to obtain positively charged $\mathrm{N}-\mathrm{TiO}_{2}-\mathrm{NH}_{2} \mathrm{NPs}$, whose surfaces were full of the protonated amino groups $\left(-\mathrm{NH}_{3}{ }^{+}\right)$. FA and $\mathrm{N}-\mathrm{Hydroxysuccinimide} \mathrm{(NHS)} \mathrm{were} \mathrm{reacted} \mathrm{to} \mathrm{form}$ NHS-FA, then FA was conjugated with $\mathrm{N}-\mathrm{TiO}_{2}-\mathrm{NH}_{2}$ following a standard procedure [22]. It should be noted that FA has $\alpha$ - and $\gamma$-carboxylic acids and both of them could react with NHS. In such a reaction, the $\gamma$-carboxylic acid is primarily conjugated due to its higher reactivity [23].

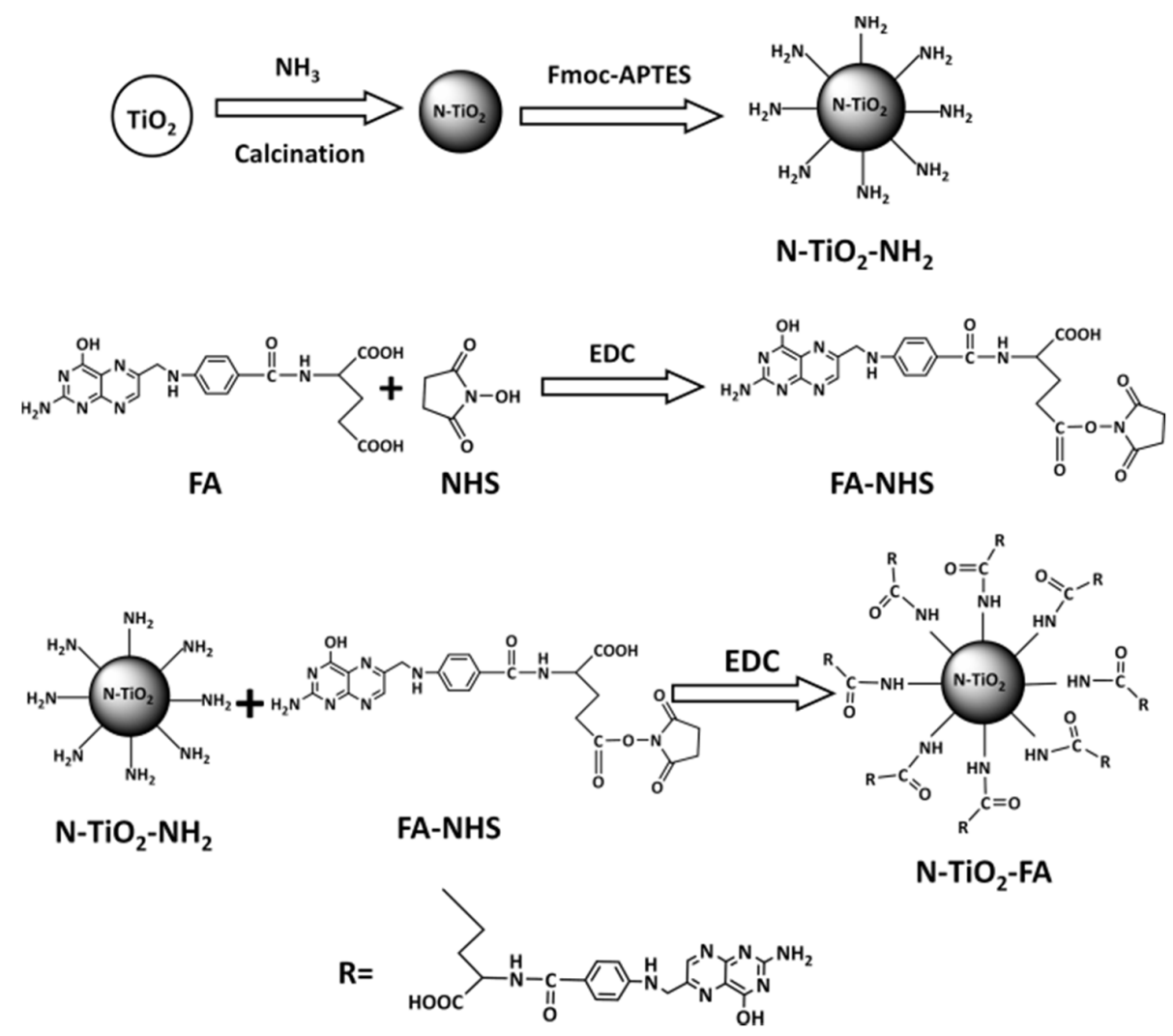

Figure 1. Synthesis procedure of $\mathrm{N}-\mathrm{TiO}_{2}$-folic acid (FA) nanoparticles (NPs). 
The absorbance spectra of $\mathrm{N}-\mathrm{TiO}_{2}-\mathrm{FA}$ and $\mathrm{N}-\mathrm{TiO}_{2}-\mathrm{NH}_{2}$ solutions were measured and analyzed. The absorption spectrum of $\mathrm{N}-\mathrm{TiO}_{2}-\mathrm{FA}$ subtracting that of $\mathrm{N}-\mathrm{TiO}_{2}-\mathrm{NH}_{2}$ with the same concentration of $10 \mu \mathrm{g} \cdot \mathrm{mL}^{-1}$ was shown in Figure 2A. It can be seen that the subtracting spectrum was very similar with the spectrum of $1 \mu \mathrm{g} \cdot \mathrm{mL}^{-1}$ FA solution, which indicated that FA was successfully linked with the NPs. As shown in Figure 2B, the absorption spectra of $\mathrm{N}-\mathrm{TiO}_{2}$ and $\mathrm{N}-\mathrm{TiO}_{2}-\mathrm{FA}$ NPs were both in the visible region between 400 and $550 \mathrm{~nm}$. The absorption of $\mathrm{N}-\mathrm{TiO}_{2}$ was similar to the previous

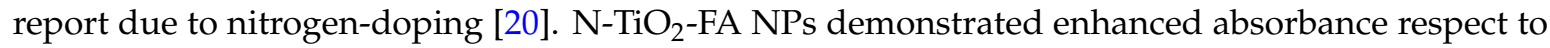
$\mathrm{N}-\mathrm{TiO}_{2}$, which may be attributed to the surface modifier. The higher absorption of $\mathrm{N}-\mathrm{TiO}_{2}-\mathrm{FA}$ might lead to higher photoactivity under visible light. The thermogravimetric analysis (TGA) of the air-dried $\mathrm{N}-\mathrm{TiO}_{2}, \mathrm{~N}-\mathrm{TiO}_{2}-\mathrm{NH}_{2}$, and $\mathrm{N}-\mathrm{TiO}_{2}-\mathrm{FA}$ NPs were shown in Figure $2 \mathrm{C}$. The weight losses at $800{ }^{\circ} \mathrm{C}$ of $\mathrm{N}-\mathrm{TiO}_{2}, \mathrm{~N}-\mathrm{TiO}_{2}-\mathrm{NH}_{2}$, and $\mathrm{N}-\mathrm{TiO}_{2}-\mathrm{FA}$ NPs were 2.26, 5.75, and $11.87 \mathrm{wt} \%$, respectively. The weight loss of $\mathrm{N}-\mathrm{TiO}_{2}-\mathrm{NH}_{2} \mathrm{NPs}$ with respect to $\mathrm{N}-\mathrm{TiO}_{2}$ was $3.49 \mathrm{wt} \%$, which was due to the amino silane coupling agent. It could be estimated that the conjugated amount of $-\mathrm{NH}_{2}$ on one $\mathrm{N}-\mathrm{TiO}_{2} \mathrm{NP}$ was 205 by assuming $\mathrm{N}-\mathrm{TiO}_{2} \mathrm{NPs}$ were spheres with the diameter of $10 \mathrm{~nm}$. The weight loss of $\mathrm{N}-\mathrm{TiO} 2-\mathrm{FA}$ NPs with respect to $\mathrm{N}-\mathrm{TiO}_{2}-\mathrm{NH}_{2}$ was $6.12 \mathrm{wt} \%$, which was due to the disappearance of FA. Thus, the conjugated amount of $\mathrm{FA}$ on one $\mathrm{N}-\mathrm{TiO}_{2} \mathrm{NP}$ was further estimated about 193. According to the TGA result, one can conclude that almost all of the amino coupling agents were conjugated with FA.
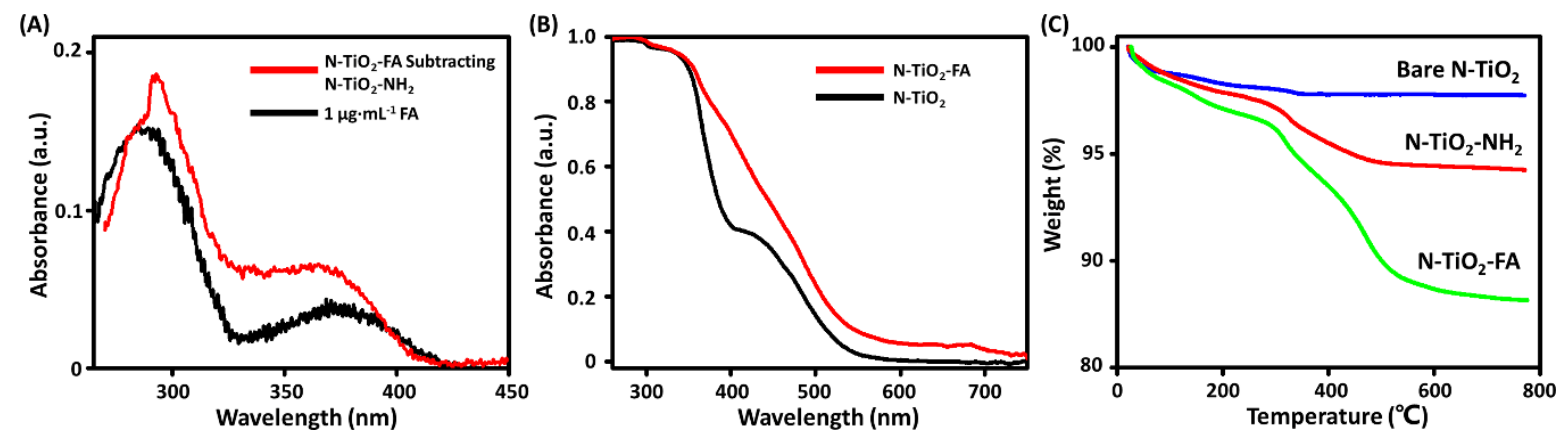

Figure 2. (A) Comparison of the absorption spectrum of $1 \mu \mathrm{g} \cdot \mathrm{mL}^{-1}$ folic acid (FA) solution and the subtraction spectrum of $\mathrm{N}-\mathrm{TiO}_{2}-\mathrm{FA}$ subtracting $\mathrm{N}-\mathrm{TiO}_{2}-\mathrm{NH}_{2} ;\left(\right.$ B) Absorption spectra of $\mathrm{N}-\mathrm{TiO}_{2}$ and $\mathrm{N}-\mathrm{TiO}_{2}$-FA NPs; (C) Thermogravimetric analysis of the air-dried $\mathrm{N}-\mathrm{TiO}_{2}, \mathrm{~N}-\mathrm{TiO}_{2}-\mathrm{NH}_{2}$ and $\mathrm{N}-\mathrm{TiO}_{2}$-FA NPs.

The surface electrical property of samples was studied by Zeta potential measurement. It is well known that when the absolute value of Zeta potential is above $30 \mathrm{mV}$, the NPs can be stably dispersed in the solvent [24]. The Zeta potential of $\mathrm{N}-\mathrm{TiO}_{2}$ was $-10.4 \pm 0.6 \mathrm{mV}$, which was negatively charged and with poor dispersibility. Capping with cationic amino groups, the Zeta potential of the positively charged $\mathrm{N}_{-} \mathrm{TiO}_{2}-\mathrm{NH}_{2}$ was $+20.6 \pm 2.3 \mathrm{mV}$. As FA conjugated on $\mathrm{N}-\mathrm{TiO}_{2} \mathrm{NPs}, \mathrm{N}-\mathrm{TiO}_{2}-\mathrm{FA}$ became negatively charged $(-27.4 \pm 1.2 \mathrm{mV})$ and more stably dispersed in solution at $\mathrm{pH}=7$. These results confirmed that FA was successfully conjugated with $\mathrm{N}-\mathrm{TiO}_{2} \mathrm{NPs}$ and implied that the obtained $\mathrm{N}-\mathrm{TiO}_{2}$-FA NPs had good dispersibility.

\subsection{Cellular Uptake}

The cellular uptake of unmodified $\mathrm{TiO}_{2}$ NPs is inefficient due to their poor dispersibility, while $\mathrm{N}-\mathrm{TiO}_{2}-\mathrm{FA}$ NPs with improved dispersibility can enter cells. According to our previous result, $\mathrm{TiO}_{2}$ NPs could enter cells non-specifically [24]. It was reported that the negatively charged $\mathrm{TiO}_{2} \mathrm{NPs}$ entered HeLa cells by various pathways such as caveolin-mediated endocytosis, clathrin-mediated endocytosis, and micropinocytosis. When cells were incubated in $4{ }^{\circ} \mathrm{C}$, there were still some $\mathrm{TiO}_{2} \mathrm{NPs}$ entering HeLa cells [24]. In this study, KB cells as the FR-positive cancer cells and A549 cells as the FR-negative cancer cells were cultured to investigate the cellular uptake of $\mathrm{N}-\mathrm{TiO}_{2}-\mathrm{FA}$ with the same condition. After $40 \mathrm{~min}$ incubation with culture medium containing $50 \mu \mathrm{g} \cdot \mathrm{mL}^{-1} \mathrm{~N}-\mathrm{TiO}_{2}-\mathrm{FA}, \mathrm{KB}$ cells 
exhibited higher reflection intensity of internalized $\mathrm{N}-\mathrm{TiO}_{2}-\mathrm{FA}$ than $\mathrm{A} 549$ cells as shown in Figure 3A. Moreover, it can be seen that some of $\mathrm{N}-\mathrm{TiO}_{2}-\mathrm{FA}$ NPs were around the cell membranes of A549, instead of inside. This suggests that the cellular uptake of $\mathrm{TiO}_{2}-\mathrm{FA}$ NPs was more effective for FR-positive KB cells. The average amount of $\mathrm{N}-\mathrm{TiO}_{2}-\mathrm{FA}$ NPs located in $\mathrm{KB}, \mathrm{A} 549$ and FA-pretreated $\mathrm{KB}$ or A549 cells with increasing incubation time were quantified by analyzing the reflection intensity of $\mathrm{N}-\mathrm{TiO}_{2}-\mathrm{FA}$ NPs inside individual cells. As shown in Figure 3B, the amounts of endocytosed $\mathrm{N}_{-} \mathrm{TiO}_{2}-\mathrm{FA}$ NPs in KB cells were about twice that in A549 cells and FA-pretreated cells. For the FA-pretreated KB cells, the receptors of $\mathrm{KB}$ cells were occupied by loaded $\mathrm{FA}$, so the amount of $\mathrm{N}-\mathrm{TiO}_{2}-\mathrm{FA}$ in $\mathrm{FA}$-pretreated $\mathrm{KB}$ cells was similar with those of A549 cells. This result also confirmed that FA was successfully linked with $\mathrm{N}-\mathrm{TiO}_{2} \mathrm{NPs}$ and the $\mathrm{N}-\mathrm{TiO}_{2}-\mathrm{FA} \mathrm{NPs}$ could target FR-positive cancer cells with high efficiency. Figure 3B showed that the amount of $\mathrm{N}-\mathrm{TiO}_{2}-\mathrm{FA}$ in FA-pretreated A549 cells decreased by around $10 \%$ compared with non-pretreated A549 cells. Therefore, it can be concluded that FA can only block

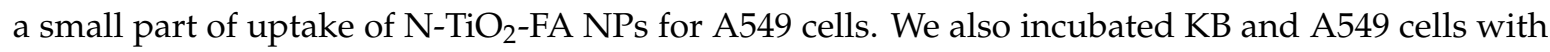
$\mathrm{N}-\mathrm{TiO}_{2}$ for $40 \mathrm{~min}$ and found that the amounts of $\mathrm{N}-\mathrm{TiO}_{2}$ in cells were similar to those of FA-pretreated ones. This result proved that the coupled FA on $\mathrm{N}^{-\mathrm{TiO}_{2}} \mathrm{NPs}$ improved the uptake efficiency of NPs for FR-positive cancer cells.

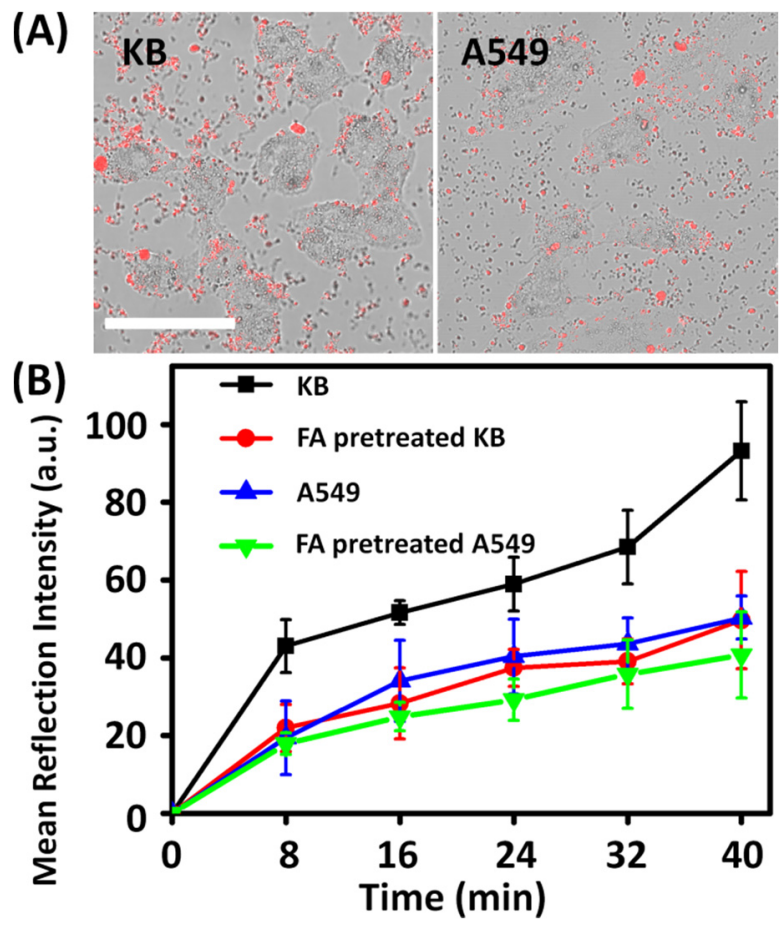

Figure 3. (A) Confocal microscopic images of human nasopharyngeal carcinoma (KB) and human pulmonary adenocarcinoma (A549) cells treated with $\mathrm{N}-\mathrm{TiO}_{2}$-FA (red) for $40 \mathrm{~min}$. Scale bar is $50 \mu \mathrm{m}$. (B) Reflection intensity of internalized $\mathrm{N}-\mathrm{TiO}_{2}-\mathrm{FA}$ in $\mathrm{KB}$ (black), FA-pretreated $\mathrm{KB}$ (red), A549 (blue) cells and FA-pretreated A549 (green) as a function of incubation time.

\subsection{Cytotoxicity of $\mathrm{N}-\mathrm{TiO}_{2}-\mathrm{FA}$}

The cell viability assays of KB and A549 cells were measured after the cells were incubated with 50-200 $\mu \mathrm{g} \cdot \mathrm{mL}^{-1} \mathrm{~N}-\mathrm{TiO}_{2}-\mathrm{FA}$ for $1 \mathrm{~h}$ in order to evaluate its cytotoxicity. As shown in Figure 4 , all the surviving fractions of the treated cells were greater than $90 \%$. It can be concluded that nitrogen-doping, surface-modification or coupling with FA has little influence on cytotoxicity. These results also showed that the cytotoxicity of the $\mathrm{N}-\mathrm{TiO}_{2}-\mathrm{FA}$ NPs is quite low and negligible, indicating that $\mathrm{N}-\mathrm{TiO}_{2}-\mathrm{FA} \mathrm{NPs}$ are well biocompatible, safe in dark, and of therapy application value. 


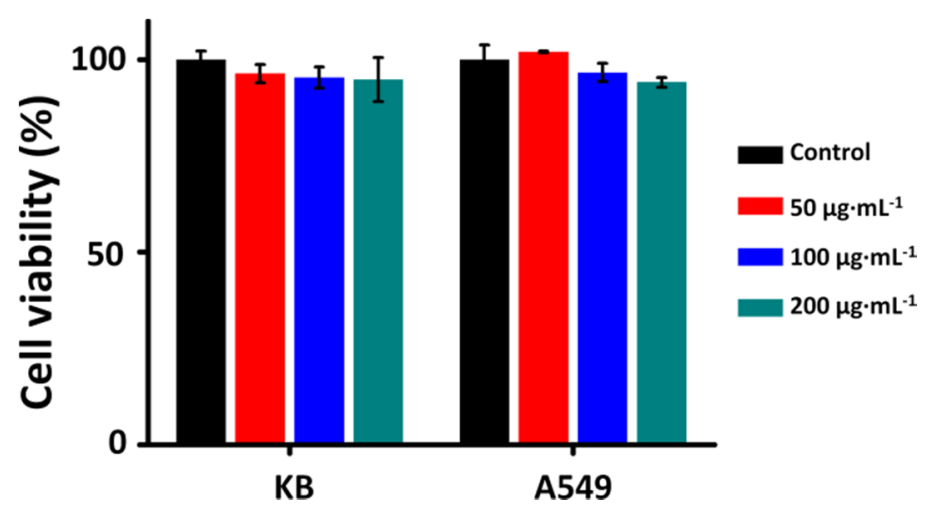

Figure 4. The dark cytotoxicity of $\mathrm{N}^{-\mathrm{TiO}_{2}}$-FA with the incubation concentrations of $50-200 \mu \mathrm{g} \cdot \mathrm{mL}^{-1}$ on KB and A549 cells. The control groups of untreated cells were also shown for comparison. Data are expressed as mean $\pm \mathrm{SD}(n=4)$.

\subsection{Targeting and Photokilling Effect on Cancer Cells}

The photokilling effects were measured under visible-light irradiation (400-575 nm) of the light dose $190 \mathrm{~J} \cdot \mathrm{cm}^{-2}$. The surviving fractions of KB and A549 cells in dependence on the kinds of photosensitizer samples were shown in Figure 5. $\mathrm{N}-\mathrm{TiO}_{2}-\mathrm{NH}_{2}$ showed a weak and similar photokilling effect on both cell lines with about $80 \%$ survival fractions. $\mathrm{N}-\mathrm{TiO}_{2}-\mathrm{FA}$ showed a higher photokilling effect on A549 cells with $68.9 \%$ cell viability which is due to its better dispersibility with the comparison of $\mathrm{N}-\mathrm{TiO}_{2}-\mathrm{NH}_{2}$. However, $\mathrm{N}-\mathrm{TiO}_{2}-\mathrm{FA}$ exhibited an excellent photokilling effect on $\mathrm{KB}$ cells with the cell viability dropping to $34.5 \%$. Compared with $\mathrm{N}-\mathrm{TiO}_{2}-\mathrm{NH}_{2}$, the $\mathrm{N}-\mathrm{TiO}_{2}-\mathrm{FA} \mathrm{NPs}$ demonstrated the targeting specificity for FR and exhibited a better photokilling effect on FR-positive tumor cells, which we can attribute to the coupling with FA.

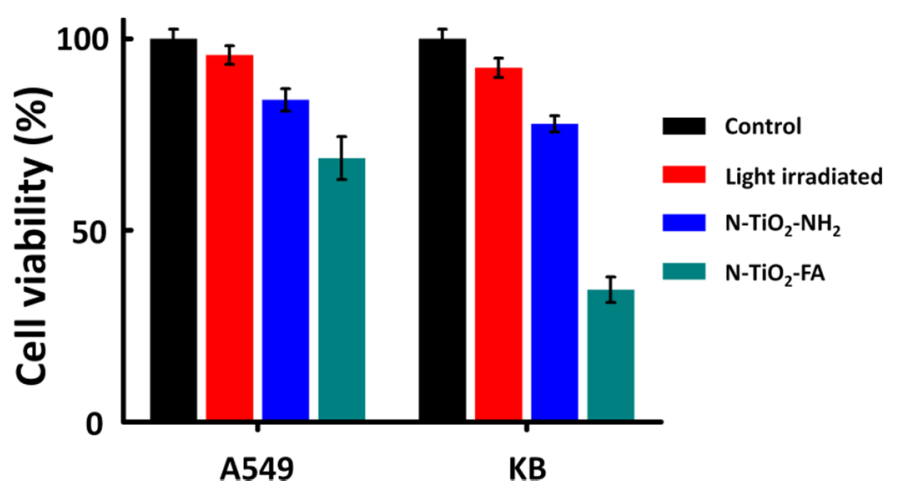

Figure 5. Photokilling effects of $\mathrm{N}-\mathrm{TiO}_{2}-\mathrm{FA}$ (green) and $\mathrm{N}-\mathrm{TiO}_{2}-\mathrm{NH}_{2}$ (blue) with the concentration of $200 \mu \mathrm{g} \cdot \mathrm{mL}^{-1}$ on $\mathrm{A} 549$ and $\mathrm{KB}$ cells. The control group (black) and light irradiated group (red) were also shown for comparison. Data are expressed as mean $\pm \operatorname{SD}(n=4)$.

\section{Discussion}

Wang et al. [25] evaluated the effectiveness of nano- $\mathrm{TiO}_{2}$-based PDT with UV light on glioma. They conducted the experiment on female BALB/c-nude mice with the treatment solutions containing $200 \mu \mathrm{g} \cdot \mathrm{mL}^{-1} \mathrm{TiO}_{2}$ and the dosage of $\mathrm{TiO}_{2}$ in mice was about $10 \mathrm{mg} \cdot \mathrm{kg}^{-1}$. You et al. [26] conducted sonodynamic therapy using $\mathrm{TiO}_{2}$ with the dosage of $100 \mu \mathrm{g} \cdot \mathrm{mL}^{-1}$ in vitro and $5 \mathrm{mg} \cdot \mathrm{kg}^{-1}$ in mice. Considering these reports, the solution concentration of $200 \mu \mathrm{g} \cdot \mathrm{mL}^{-1}$ in this study could be therapeutic in vivo and the dosage of NPs should be decided according to the weight of the experiment animals.

Compared with the much more common gold nanorods [27], the cetyltrimethylammonium bromide $(\mathrm{CTAB})$ as the initial stabilizer of gold nanorods exhibits inevitable toxicity in biological 
issues [28]. Additionally, the nitrogen-doped $\mathrm{TiO}_{2}$ particles can be prepared fruitfully by an easily operative method with much lower cost. Moreover, the nitrogen-doped $\mathrm{TiO}_{2}$ particles possess the photosensitizing properties in visible light, while gold nanorods were often used as the carrier of the tradition photosensitizers $[29,30]$. Therefore, nitrogen-doped $\mathrm{TiO}_{2}$ nanoparticles were of high value in therapy applications.

\section{Materials and Methods}

\subsection{Materials}

Anatase $\mathrm{TiO}_{2}$ NPs (Sigma-Aldrich Inc., St. Louis, MO, USA) with a nominal diameter less than $15 \mathrm{~nm}$ were used in this study. An activated silane coupling agent 3-aminopropyltriethoxysilane (APTES, 99\%, Aladdin Inc., Shanghai, China) was used for positive charge modification of $\mathrm{TiO}_{2}$ NPs. Other chemical agents involved in positive charge modification include Dimethylformamide (DMF, 98\%, Sinopharm Chemical Reagent Co., Ltd., Shanghai, China), 2-(9H-fluoren-9-ylmethoxycarbonylamino)oxyacetic acid (Fmoc-Aoa, Chem-Impex International, Inc., Wood Dale, IL, USA), N,N-Diisopropylethylamine (DIPEA, 99.5\%, Sigma-Aldrich Inc., St. Louis, MO, USA), (Benzotriazole-1-yloxy)tripyrrolidinophosphonium hexafluorophosphate (PyBOP, 98\%, EMD Chemicals, Inc., Gibbstown, NJ, USA), piperidine ( $\geqslant 99.5 \%$, Sigma-Aldrich Inc., St. Louis, MO, USA), and ammonium solution ( $25 \%-28 \%$, Tongsheng Inc., Yixing, China). The chemical agents used in the conjugation of folic acid on $\mathrm{TiO}_{2} \mathrm{NPs}$ were folic acid (FA, $\geqslant 97 \%$, Sigma-Aldrich), dimethyl sulfoxide (DMSO, $\geqslant 99.7 \%$, Sigma-Aldrich), 1-(3-Dimethylaminopropyl)-3-ethylcarbodiimide hydrochloride (EDC, 99\%, Sigma-Aldrich), and N-Hydroxysuccinimide (NHS, 99\%, Sigma-Aldrich).

\subsection{Preparation of $\mathrm{N}-\mathrm{TiO}_{2}-\mathrm{FA}$}

The anatase $\mathrm{TiO}_{2} \mathrm{NPs}$ were first calcinated in ammonia atmosphere to obtain nitrogen-doping $\mathrm{TiO}_{2}\left(\mathrm{~N}-\mathrm{TiO}_{2}\right) \mathrm{NPs}$ as described in our previous work [20]. The $\mathrm{N}-\mathrm{TiO}_{2}$ nanoparticles were modified with APTES to obtain positively charged $\mathrm{N}-\mathrm{TiO}_{2}-\mathrm{NH}_{2} \mathrm{NPs}$ following the procedure in our previous work [24]. In brief, $0.7 \mathrm{~mL}$ APTES, $0.94 \mathrm{mg}$ Fmoc-Aoa $(1 \mathrm{mM}), 3.122 \mathrm{mg}$ PyBOP $(2 \mathrm{mM})$ and $1 \mu \mathrm{L}$ DIPEA $(0.5 \mathrm{mM})$ were dispersed in $2.3 \mathrm{~mL} \mathrm{DMF}$, followed by stirring for $12 \mathrm{~h}$ at room temperature. Then $0.7 \mathrm{mg} \mathrm{TiO} 2,0.7 \mathrm{~mL}$ ammonia water and $3.3 \mathrm{~mL}$ DMF were added into the stirred solution. The produced suspension was sonicated for $20 \mathrm{~min}$ and stirred for another $24 \mathrm{~h}$ before adding $70 \mu \mathrm{L}$ redistilled piperidine. The positively charged $\mathrm{N}-\mathrm{TiO}_{2}-\mathrm{NH}_{2}$ was obtained by stirring the reaction solution for $12 \mathrm{~h}$. Subsequently, FA $(0.011 \mathrm{mM})$, EDC $(0.003 \mathrm{mM})$ and NHS $(0.003 \mathrm{mM})$ with a mole ratio of 10:3:3 were placed in a flask and dissolved in $20 \mathrm{~mL}$ DMSO to prepare NHS-FA, and then $1 \mathrm{mg} \mathrm{N}-\mathrm{TiO}_{2}-\mathrm{NH}_{2}$ was dispersed in it, followed by an ultrasonic dispersion for $15 \mathrm{~min}$. The mixture solution was stirred to react at room temperature for $12 \mathrm{~h}$. The $\mathrm{N}-\mathrm{TiO}_{2}-\mathrm{FA}$ sample was separated from the reaction mixture by centrifugation at $8000 \mathrm{rpm}$ for $30 \mathrm{~min}$ and washed by DMSO once and by deionized water twice to remove the excess FA, EDC and NHS.

\subsection{Characterization of Samples}

The Zeta potentials of $\mathrm{N}-\mathrm{TiO}_{2}-\mathrm{FA}, \mathrm{N}-\mathrm{TiO}_{2}-\mathrm{NH}_{2}$, as well as bare $\mathrm{TiO}_{2} \mathrm{NPs}$ dissolved in deionized water with the concentration of $50 \mu \mathrm{g} \cdot \mathrm{mL}^{-1}$ were measured by Zetasizer Nano ZS90 (Malvern Instruments; Worcestershire; UK) at $25^{\circ} \mathrm{C}$ and $\mathrm{pH}=7$. Absorption spectra of the samples were measured using a spectrometer (Shimadzu, UV3101pc; Japan). Thermogravimetric analysis (TGA) for the air-dried $\mathrm{N}-\mathrm{TiO}_{2}, \mathrm{~N}-\mathrm{TiO}_{2}-\mathrm{NH}_{2}$ and $\mathrm{N}-\mathrm{TiO}_{2}-\mathrm{FA} \mathrm{NPs}$ was performed on a SDT Q600 (TA Instrument, New Castle, DE, USA) from 20 to $800^{\circ} \mathrm{C}$ at a heating rate of $10^{\circ} \mathrm{C} \cdot \mathrm{min}^{-1}$ under $\mathrm{N}_{2}$ flow.

\subsection{Cell Culture}

KB and A549 cells were cultured in RPMI-1640 medium (Roswell Park Memorial Institute 1640, Gibco, New York, NY, USA) with 10\% $(v / v)$ fetal bovine serum (Sijiqing Inc., Zhejiang, China) in 
a humidified standard incubator with a $\mathrm{CO}_{2}$ atmosphere at $37^{\circ} \mathrm{C}$. The cells were seeded in Petri dishes or 96-well plates according to experimental needs. All experiments were performed after the cells have reached $80 \%$ confluence with normal morphology.

\subsection{Cellular Uptake Study of $\mathrm{N}-\mathrm{TiO}_{2}-\mathrm{FA}$}

KB or A549 cells in Petri dishes were incubated with RPMI-1640 medium containing $50 \mu \mathrm{g} \cdot \mathrm{mL}^{-1}$ $\mathrm{TiO}_{2}$-FA for 8, 16, 24, 32, or $40 \mathrm{~min}$. Then, the medium containing surplus $\mathrm{TiO}_{2} \mathrm{NPs}_{\text {s }}$ was removed and changed to fresh culture medium. For comparison, a dish of KB cells and a dish of A549 cells were treated with $500 \mu \mathrm{g} \cdot \mathrm{mL}^{-1} \mathrm{FA}$ in RPMI-1640 medium for $2 \mathrm{~h}$ before being treated with $\mathrm{N}-\mathrm{TiO}_{2}-\mathrm{FA} \mathrm{NPs}$ by the same method.

Cells in each experiment were fixed with $4 \%$ paraformaldehyde in phosphate buffered saline (PBS) solution for $10 \mathrm{~min}$ and were washed three times using PBS before observation by a laser scanning confocal microscope (LSCM, Olympus, FV300/IX 71, Tokyo, Japan), which is equipped with a $488 \mathrm{~nm}$ $\mathrm{Ar}^{+}$continuous laser excitation (Coherent, Santa Clara, CA, USA) and a water-dipping objective $(60 \times$, $\mathrm{NA}=1.2$ ).

The cellular uptake of $\mathrm{N}-\mathrm{TiO}_{2}-\mathrm{FA}$ and $\mathrm{N}-\mathrm{TiO}_{2} \mathrm{NPs}$ were observed by the LSCM. The reflection images of the $\mathrm{TiO}_{2}$ NPs were obtained through a channel of the microscope without filter. The differential interference contrast (DIC) micrographs were observed simultaneously in a transmission channel to demonstrate the cell morphology and identify the borders of the cells. The quantitative study of $\mathrm{N}-\mathrm{TiO}_{2}$-FA NPs was analyzed using an open source software ImageJ to evaluate the reflection intensity of NPs inside individual cells. At least 50 cells were analyzed for each condition.

\subsection{Measurements of Photokilling Effect and Cytotoxicity}

$\mathrm{KB}$ or A549 cells grown in 96-well plates $\left(1 \times 10^{5}\right.$ cells per well $)$ were incubated with $\mathrm{TiO}_{2}-\mathrm{FA}$ NPs dispersed in RPMI-1640 medium with different concentrations between 50 and $200 \mu \mathrm{g} \cdot \mathrm{mL}^{-1}$ for $1 \mathrm{~h}$ in the dark. Then the medium was removed and replaced by fresh culture medium.

To study the photokilling effect, the cells were irradiated by an 18-W tungsten halogen lamp. Two pieces of quartz lens were used to obtain a concentrated parallel light beam and two filters were used to obtain a light beam of 400-575 $\mathrm{nm}$. The visible-light illumination dose for cells was $190 \mathrm{~J} \cdot \mathrm{cm}^{-2}$. After irradiation, the cells were incubated in the dark for $24 \mathrm{~h}$ before further study. The cytotoxicity examinations were carried out with the same procedure as the photokilling effect but without irradiation.

The cell viability assays were conducted by a modified MTT method using WST-8 (2-(2-methoxy-4-nitrophenyl)-3-(4-nitrophenyl)-5-(2, 4-disulfophenyl)-2H tetrazolium, monosodium salt, Beyotime, Jiangsu, China). Each well containing $100 \mu \mathrm{L}$ culture medium was added with $10 \mu \mathrm{L}$ of WST-8. The cells were incubated at $37^{\circ} \mathrm{C}$ with $5 \% \mathrm{CO}_{2}$ for $2 \mathrm{~h}$ and the absorbance was measured at $450 \mathrm{~nm}$ using a microplate reader (Bio-Tek Instruments Inc., Winooski, VT, USA). To diminish the influence of the NPs, the absorbance values at $450 \mathrm{~nm}$ before adding WST- 8 dyes were also measured as a reference. Cells incubated in RPMI-1640 medium without any treatment were used as the control group. Each experiment was conducted and measured independently for at least three times.

\section{Conclusions}

In this study, we have successfully produced $\mathrm{N}-\mathrm{TiO}_{2}-\mathrm{FA}$ nanoconjugates. Zeta potential results showed that $\mathrm{N}-\mathrm{TiO}_{2}-\mathrm{FA}$ had a negative Zeta potential and possessed good dispersibility. The absorption spectra and TGA result showed that FA was connected to the surface of $\mathrm{N}^{-\mathrm{TiO}_{2}} \mathrm{NPs}$. The incubation experiment results showed that $\mathrm{N}-\mathrm{TiO}_{2}-\mathrm{FA}$ had higher uptake efficiency in FR-positive $\mathrm{KB}$ cells than FR-negative A549 cells, as well as the FA-pretreated cells. Finally, N-TiO $2-\mathrm{FA}$ had no obvious cytotoxicity, but had a significant photokilling effect on FR-positive KB cells with visible light illumination. Therefore, $\mathrm{N}-\mathrm{TiO}_{2}-\mathrm{FA}$ can be of high value as a PS for cancer targeting PDT. 
Acknowledgments: The authors are grateful to the support of National Natural Science Foundation of China (11574056, 31500599, 61505032).

Author Contributions: Jin Xie performed the experiments and drafted the manuscript; Xiaobo Pan and Mengyan Wang contributed by assisting in experimental setup; Longfang Yao and Xinyue Liang contributed the cell samples preparation; Jiong Ma, Yiyan Fei and Pei-Nan Wang contributed instruction of data collection and interpretation; Lan Mi designed the experiments, contributed as the advisor to the research, and revised and edited the manuscript.

Conflicts of Interest: The authors declare no conflict of interest.

\section{References}

1. Dougherty, T.J.; Gomer, C.J.; Henderson, B.W.; Jori, G.; Kessel, D.; Korbelik, M.; Moan, J.; Peng, Q. Photodynamic therapy. J. Natl. Cancer Inst. 1998, 90, 889-905. [CrossRef] [PubMed]

2. Dolmans, D.E.; Fukumura, D.; Jain, R.K. Photodynamic therapy for cancer. Nat. Rev. Cancer 2003, 3, 380-387. [CrossRef] [PubMed]

3. Kamkaew, A.; Lim, S.H.; Lee, H.B.; Kiew, L.V.; Chung, L.Y.; Burgess, K.; Burgess, K. BODIPY dyes in photodynamic therapy. Chem. Soc. Rev. 2013, 42, 77-88. [CrossRef] [PubMed]

4. Lin, J.; Wang, S.J.; Huang, P.; Wang, Z.; Chen, S.H.; Niu, G.; Li, W.W.; He, J.; Cui, D.X.; $\mathrm{Lu}, \mathrm{G} . \mathrm{M}$. Photosensitizer-loaded gold vesicles with strong plasmonic coupling effect for imaging-guided photothermal/photodynamic therapy. ACS Nano 2013, 7, 5320-5329. [CrossRef] [PubMed]

5. Pelaez, M.; Nolan, N.T.; Pillai, S.C.; Seery, M.K.; Falaras, P.; Kontos, A.G.; Dunlop, P.S.M.; Hamilton, J.W.J.; Byrne, J.A.; O'shea, K. A review on the visible light active titanium dioxide photocatalysts for environmental applications. Appl. Catal. B 2012, 125, 331-349. [CrossRef]

6. Shi, H.; Magaye, R.; Castranova, V.; Zhao, J.S. Titanium dioxide nanoparticles: A review of current toxicological data. Part. Fibre Toxicol. 2013, 10. [CrossRef] [PubMed]

7. Bai, Y.; Mora-Seró, I.; De Angelis, F.; Bisquert, J.; Wang, P. Titanium dioxide nanomaterials for photovoltaic applications. Chem. Rev. 2014, 114, 10095-10130. [CrossRef] [PubMed]

8. Ma, W.; Yi, S.G.; Lin, L.W.; Huang, H.; Peng, T.; Liu, Z.T.; Liu, Z.P.; Pei, D.N.; Miao, X.Y.; Wen, Y. Anticancer Effect of Photodynamic Therapy with Photosan-Loaded Titanium Dioxide Nanoparticles on Panc-1 Pancreatic Cancer Cells In Vitro. Sci. Adv. Mat. 2016, 8, 1145-1153. [CrossRef]

9. Zhang, S.C.; Yang, D.J.; Jing, D.W.; Liu, H.W.; Liu, L.; Jia, Y.; Gao, M.H.; Guo, L.J.; Huo, Z.Y. Enhanced photodynamic therapy of mixed phase $\mathrm{TiO}_{2}$ (B)/anatase nanofibers for killing of HeLa cells. Nano Res. 2014, 7, 1659-1669. [CrossRef]

10. Yin, Z.F.; Wu, L.; Yang, H.G.; Su, Y.H. Recent progress in biomedical applications of titanium dioxide. Phys. Chem. Chem. Phys. 2013, 15, 4844-4858. [CrossRef] [PubMed]

11. Pan, X.; Xie, J.; Li, Z.; Chen, M.; Wang, P.N.; Chen, L.; Mi, L. Enhancement of the photokilling effect of aluminum phthalocyanine in photodynamic therapy by conjugating with nitrogen-doped $\mathrm{TiO}_{2}$ nanoparticles. Colloids Surf. B 2015, 130, 292-298. [CrossRef] [PubMed]

12. Tokuoka, Y.; Yamada, M.; Kawashima, N.; Miyasaka, T.; Miyasaka, T. Anticancer effect of dye-sensitized $\mathrm{TiO}_{2}$ nanocrystals by polychromatic visible light irradiation. Chem. Lett. 2006, 35, 496-497. [CrossRef]

13. Li, Z.; Pan, X.; Wang, T.; Wang, P.N.; Chen, J.Y.; Mi, L. Comparison of the killing effects between nitrogen-doped and pure $\mathrm{TiO}_{2}$ on HeLa cells with visible light irradiation. Nanoscale Res. Lett. 2013, 8. [CrossRef] [PubMed]

14. Jańczyk, A.; Wolnicka-Głubisz, A.; Urbanska, K.; Stochel, G.; Macyk, W. Photocytotoxicity of platinum (IV)-chloride surface modified $\mathrm{TiO}_{2}$ irradiated with visible light against murine macrophages. J. Photochem. Photobiol. B 2008, 92, 54-58. [CrossRef] [PubMed]

15. Parker, N.; Turk, M.J.; Westrick, E.; Lewis, J.D.; Low, P.S.; Leamon, C.P. Folate receptor expression in carcinomas and normal tissues determined by a quantitative radioligand binding assay. Anal. Biochem. 2005, 338, 284-293. [CrossRef] [PubMed]

16. Hilgenbrink, A.R.; Low, P.S. Folate receptor-mediated drug targeting: From therapeutics to diagnostics. J. Pharm. Sci. 2005, 94, 2135-2146. [CrossRef] [PubMed]

17. Hu, Z.; Li, J.; Li, C.; Zhao, S.; Li, N.; Wang, Y.; Wei, F.; Chen, L.; Huang, Y. Folic acid-conjugated graphene-ZnO nanohybrid for targeting photodynamic therapy under visible light irradiation. J. Mater. Chem. B 2013, 1, 5003-5013. [CrossRef] 
18. Huang, P.; Bao, L.; Zhang, C.; Lin, J.; Luo, T.; Yang, D.; He, M.; Li, Z.; Gao, G.; Gao, B. Folic acid-conjugated silica-modified gold nanorods for X-ray/CT imaging-guided dual-mode radiation and photo-thermal therapy. Biomaterials 2011, 32, 9796-9809. [CrossRef] [PubMed]

19. Lai, T.Y.; Lee, W.C. Killing of cancer cell line by photoexcitation of folic acid-modified titanium dioxide nanoparticles. J. Photochem. Photobiol. A 2009, 204, 148-153. [CrossRef]

20. Li, Z.; Mi, L.; Wang, P.N.; Chen, J. Study on the visible-light-induced photokilling effect of nitrogen-doped $\mathrm{TiO}_{2}$ nanoparticles on cancer cells. Nanoscale Res. Lett. 2011, 6, 1-7. [CrossRef] [PubMed]

21. Ye, L.; Pelton, R.; Brook, M.A. Biotinylation of $\mathrm{TiO}_{2}$ nanoparticles and their conjugation with streptavidin. Langmuir 2007, 23, 5630-5637. [CrossRef] [PubMed]

22. Hermanson, G. Bioconjugate Techniques; Acad Press: San Diego, CA, USA; New York, NY, USA; Boston, MA, USA, 1996; pp. 173-177.

23. Yoo, H.S.; Park, T.G. Folate-receptor-targeted delivery of doxorubicin nano-aggregates stabilized by doxorubicin-PEG-folate conjugate. J. Control. Release 2004, 100, 247-256. [CrossRef] [PubMed]

24. Xie, J.; Pan, X.; Wang, M.; Ma, J.; Fei, Y.; Wang, P.N.; Mi, L. The role of surface modification for TiO 2 nanoparticles in cancer cells. Colloids Surf. B 2016, 143, 148-155. [CrossRef] [PubMed]

25. Wang, C.; Cao, S.; Tie, X.; Qiu, B.; Wu, A.; Zheng, Z. Induction of cytotoxicity by photoexcitation of $\mathrm{TiO}_{2}$ can prolong survival in glioma-bearing mice. Mol. Biol. Rep. 2011, 38, 523-530. [CrossRef] [PubMed]

26. You, D.G.; Deepagan, V.G.; Um, W.; Jeon, S.; Son, S.; Chang, H.; Yoon, H.I.; Cho, Y.W.; Swierczewska, M.; Lee, S.; et al. ROS-generating $\mathrm{TiO}_{2}$ nanoparticles for non-invasive sonodynamic therapy of cancer. Sci. Rep. 2016, 6. [CrossRef] [PubMed]

27. Wang, N.; Zhao, Z.; Lv, Y.; Fan, H.; Bai, H.; Meng, H.; Long, Y.; Fu, T.; Zhang, X.; Tan, W. Gold nanorod-photosensitizer conjugate with extracellular $\mathrm{pH}$-driven tumor targeting ability for photothermal/photodynamic therapy. Nano Res. 2014, 7, 1291-1301. [CrossRef]

28. Khlebtsov, N.; Dykman, L. Biodistribution and toxicity of engineered gold nanoparticles: A review of in vitro and in vivo studies. Chem. Soc. Rev. 2011, 40, 1647-1671. [CrossRef] [PubMed]

29. Jang, B.; Choi, Y. Photosensitizer-conjugated gold nanorods for enzyme-activatable fluorescence imaging and photodynamic therapy. Theranostics 2012, 2, 190-197. [CrossRef] [PubMed]

30. Jang, B.; Park, J.Y.; Tung, C.H.; Kim, I.H.; Choi, Y. Gold nanorod-photosensitizer complex for near-infrared fluorescence imaging and photodynamic/photothermal therapy in vivo. ACS Nano 2011, 5, 1086-1094. [CrossRef] [PubMed]

(C) 2016 by the authors; licensee MDPI, Basel, Switzerland. This article is an open access article distributed under the terms and conditions of the Creative Commons Attribution (CC-BY) license (http:/ / creativecommons.org/licenses/by/4.0/). 